\title{
HYDROCHEMICAL CHARACTERISTICS AND GEOTHERMOMETRY APPLICATIONS OF HOT GROUNDWATER IN EDIPSOS AREA, NW EUBOEA (EVIA), GREECE
}

\author{
Kanellopoulos C. ${ }^{1}$, Christopoulou M. ${ }^{1}$, Xenakis M. ${ }^{1}$ and Vakalopoulos P. ${ }^{1}$ \\ ${ }^{1}$ Institute of Geology and Mineral Exploration, $1^{\text {st }}$ Spirou Louis St., Olympic Village, 13677, \\ Acharnae, Greece, ckanellopoulos@gmail.com,christopouloumaria@gmail.com, \\ markxen@igme.gr,vakalo@igme.gr
}

\begin{abstract}
In Edipsos area many hot springs occur, as a result of both active tectonic of the area and recent volcanism (Lichades volcanic center). A geochemical study of Edipsos hot groundwaters was undertaken, in order to assess the hydrochemistry of hot springs from Edipsos and re-evaluate the geothermal situation of the area. For that purpose, 12 water samples were collected and analyzed by Spectrophotometry for the main ions and by AAS, ICP-OES and ICP-MS for major and trace elements. The interpretation of the analytical data showed that the geochemistry of Edipsos hot groundwaters is controlled by three factors i) a deep magmatic source, ii) the chemical composition of the local rocks (ultramafic and carbonates) and iii) sea water. The application of chemical geothermometers is problematic because of the chemical composition of the hot groundwaters and especially the high participation of the sea water. The temperature which derives from the use of $\mathrm{Na}-\mathrm{K}-\mathrm{Ca}$ geothermometer is greater than $160^{\circ} \mathrm{C}$. Although, several studies have conducted in the area still remain unanswered questions concerning the underground circulation of the hot groundwater, in which only deep drilling data could give answers.

Keywords: geothermal energy, groundwater geochemistry, major and trace element concentration, Edipsos (Aidipsos), NW Euboea (Evia).
\end{abstract}

\section{Пєрí $\eta \Psi \eta$}

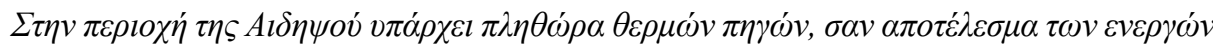

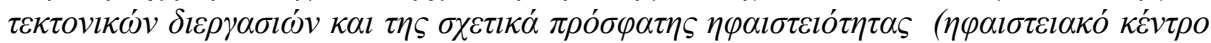

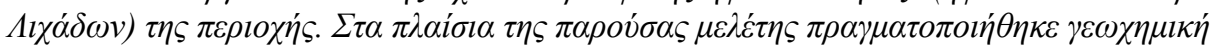

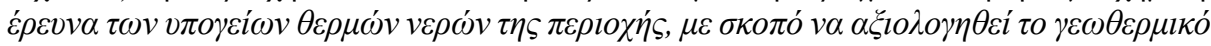

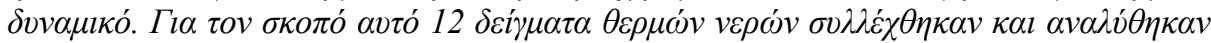

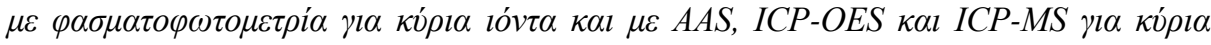

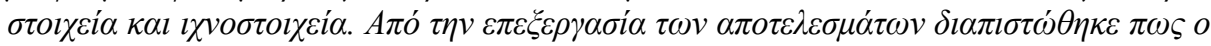

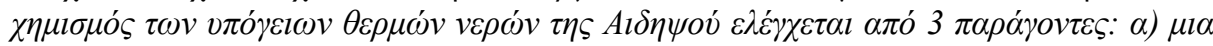

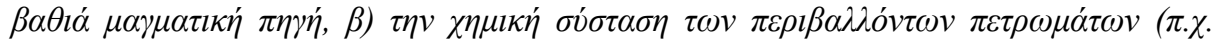

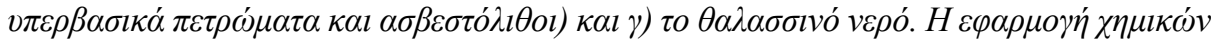

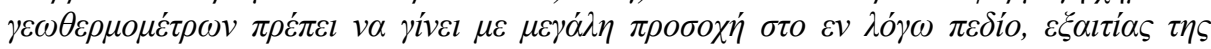

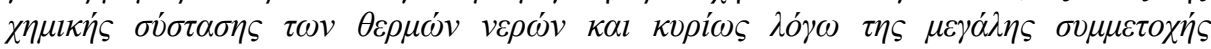

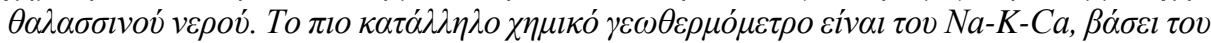

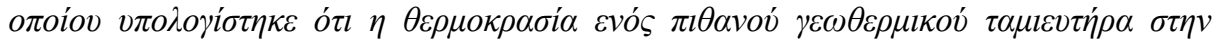




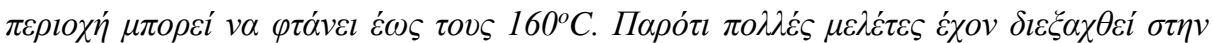

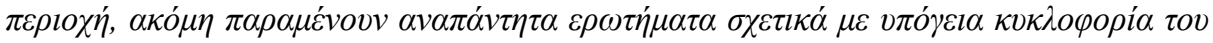

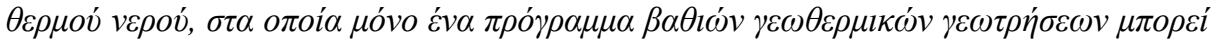
$v \alpha \delta \omega ́ \sigma \varepsilon l \alpha \pi \alpha v \tau \dot{\sigma} \sigma \varepsilon l \varsigma$.

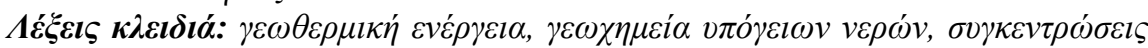

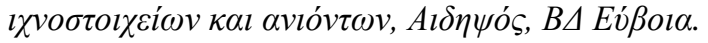

\section{Introduction}

In Greece occurs a large number of hot springs, which many of them are known since antiquity. The great number of hot springs in Greece is due to the geology of the country, which is located in the front line of the African - European tectonic plate collision-subduction zone. The combination of magmatic and volcanic processes and active fault systems favour the rise of deep waters that discharge at the surface as hot springs.

Hot waters exhibit a broad range of chemical compositions, from very dilute (a few hundred parts per million, by weight, of total dissolved constituents) to very concentrated (solutions containing tens of percent, by weight, of dissolved constituents). This dissolved load can provide important information about the characteristics of a reservoir including its temperature, mineralogy, and history. However, the dissolved load can also impact in the healing properties when is used for $\mathrm{spa}$ /bathing therapies and the performance of machinery in a geothermal power plant when is used in heating and cooling, as well as in generating power (Glassley, 2015).

From 1970-80`s, the Institute of Geological and Mineral Exploration in Greece (I.G.M.E.) performed the first systematic study on all known Greek hot springs (Orfanos, 1975; Sfetsos, 1988 etc.). Edipsos is known since ancient times for their hot springs and their healing properties. Aristotle at his study with tile Meteorology (II, 8.3) attempts to explain how hot springs of Edipsos works. Northern Euboea's hot springs and their depositions were studied by many researches in the past (Gkioni, 1998; Shimizu et al., 2005; Xatzis et al., 2008; Kanellopoulos, 2006, 2011, 2013a, 2013b; D`Alessandro et al., 2014; Dotsika, 2015).

The aim of this paper is to assess the hydrochemistry of hot springs from Edipsos and re-evaluate the geothermal situation of the area.

\section{Geological setting}

Euboea Island is located in the central part of Greece. The study area lies between the following coordinates X: 416400E, Y: 4301600N and X: 418000E, Y: 4300400N (EGSA `87). The greater area is characterized by rocky mountainous topography and some lowland areas.

Northwester part of Euboea Island belongs geologically to the western part of the internal geotectonic units of Greece, more specifically the Pelagonian and Sub-Pelagonian units (Mountrakis, 1986). The study area consists of non-metamorphic rocks, carbonate rocks, ophiolitic rocks including peridotite, gabbro, serpentinite and metamorphic rocks. Large parts of NW Euboea are covered by Post Alpine formations, Quaternary and Neogene age sediments (Fig. 1A).

In the center of northern Euboea gulf the volcanogenic islands of Lichades are located (Georgalas, 1938). They are consisted mainly of trachyandesite lava flows, dated at $0.5 \mathrm{Ma}$ (Pe-Piper and Piper, 2002). Karastathis et al. (2011) showed that there is a magma chamber, under N. Euboean Gulf, at 7-8 km depth, using low seismic P-wave velocity values and high Poisson ratios.

The study area is highly faulted due to extensional tectonics. A system of N.NE-S.SW and W.NWE.SE to NW-SE normal fault zones prevails (Vavassis, 2001; Palyvos et al., 2006). The fault zones are associated with the Northern Euboea graben, due to most recent (Quaternary) phase of the longlasting extension established in the broader back-arc area of the Hellenic arc (Mercier et al., 1989). 
In Edipsos, thermogenic travertine deposits exist created by the local hot-springs (Kanellopoulos, 2006; 2011; 2013a; 2013b).

\section{Materials and methods}

\subsection{Field work, groundwater sampling and analysis}

A total of 12 hot groundwater samples were collected (Table 1) from springs and drills used mainly for spa therapy. Unstable parameters i.e. pH, Temperature, E.C. were measured in the field.

All the samples were vacuum filtered and stored in polyethylene bottles and preserved in a refrigerator. Part of each sample was acidified to a final concentration of $2 \%$ nitric acid.

All the 12 water samples were analyzed in the Laboratories of Institute of Geological and Mineralogical Exploration (I.G.M.E.). The major element and ion concentrations were measured using spectrophotometer, or/and titration or/and AAS or and ICP-OES (Table 2). The trace element concentrations were measured using ICP-MS (Table 3).

During the field work, all the major hot springs of the area were spotted and record with GPS and in several cases photos of them were taken with a thermal camera (FLIR T640, Fig. 3).

ArcGIS was used to create a new digital optimized geological map of the greater area of Edipsos (scale 1:10,000, Fig. 1). This map was based on new field observations and the published geological maps (Marinos et al., 1957; Katsikatsos et al.,1984) of scale 1:50 000 as well as, other detailed geological maps (Tzitziras, 1996; Vavassis, 2001). A spatial database was developed in ArcGIS; physicochemical parameters and elemental concentrations were linked to the sampling points and were used in order to create a temperature spatial distribution map.

\section{Analytical results}

\subsection{Spatial distribution of temperature}

In order to visualize the spatial distribution of the shallow hot groundwater temperature in Edipsos, an interpolated map was created, based on temperature measurements from all the major hot springs and shallow wells (depth $<40 \mathrm{~m}$ ) of the area. ArcGIS software was used and kriging interpolation method was applied (Fig. 1B). Kriging is deterministic interpolation method that generates an estimated surface from a scattered set of points with z-values, in this case water temperature values.

Table 1 - Samples locality, physiochemical parameters, hydrochemical type and chemical geothermometers.

\begin{tabular}{|c|c|c|c|c|c|c|c|c|c|c|c|}
\hline \multirow[b]{2}{*}{ Code } & \multirow[b]{2}{*}{ Lon. $^{* 1}$} & \multirow[b]{2}{*}{ Lat. ${ }^{* 1}$} & \multirow[b]{2}{*}{ Locality } & \multirow[b]{2}{*}{$\begin{array}{c}\mathbf{T} \\
\left({ }^{\circ} \mathrm{C}\right)\end{array}$} & \multirow[b]{2}{*}{$\mathbf{p H}$} & \multirow[b]{2}{*}{$\begin{array}{l}\text { TDS }^{* 2} \\
(\mathrm{mg} / \mathrm{L})\end{array}$} & \multirow[b]{2}{*}{$\begin{array}{c}\text { EC } \\
(\mathrm{mS} / \mathrm{cm})\end{array}$} & \multirow[b]{2}{*}{$\begin{array}{c}\text { Hydroc. } \\
\text { type }\end{array}$} & \multicolumn{3}{|c|}{ Chemical geothermometers } \\
\hline & & & & & & & & & $Q^{t z}{ }^{* 3}$ & Na-K-Ca ${ }^{* 4}$ & $\begin{array}{c}\begin{array}{c}\text { Na-K- } \\
\mathrm{Ca}^{* 4}\end{array} \\
\text { (Mg cort.) }\end{array}$ \\
\hline STR-116G3 & 417122.1 & 4300593.0 & Thermae Sylla & 48.7 & 6.5 & 32330 & 46900 & $\mathrm{Na}-\mathrm{Cl}$ & 57 & 158 & 76 \\
\hline STR-114P2 & 417610.0 & 4300710.0 & Skourtanioti & 64.3 & 6.2 & 30875 & 43900 & $\mathrm{Na}-\mathrm{Cl}$ & 60 & 164 & 36 \\
\hline STR-114P4 & 417727.0 & 4300842.0 & $\begin{array}{l}\text { Skourtanioti- } \\
\text { Ilios }\end{array}$ & 58.1 & 6.8 & 27350 & 39900 & $\mathrm{Na}-\mathrm{Cl}$ & 56 & 157 & 77 \\
\hline STR-115G7 & 417644.1 & 4300818.0 & Kompogianni & 71.8 & 6.2 & 33365 & 46000 & $\mathrm{Na}-\mathrm{Cl}$ & 56 & 159 & 76 \\
\hline STR-114P8 & 417476.0 & 4301103.0 & Pizou-Kapelari & 60.2 & 6.0 & 32195 & 47100 & $\mathrm{Na}-\mathrm{Cl}$ & 59 & 157 & 76 \\
\hline STR-114P1A & 417376.0 & 4301182.0 & Thermopotamos & 69.0 & 6.2 & 27400 & 39100 & $\mathrm{Na}-\mathrm{Cl}$ & 56 & 157 & 77 \\
\hline STR-113GA & 417328.6 & 4300776.5 & EOT-Artemis & 79.6 & 6.2 & 33575 & 45900 & $\mathrm{Na}-\mathrm{Cl}$ & 58 & 158 & 58 \\
\hline STR-113-01 & 417283.2 & 4300846.7 & EOT-Ntamaria & 70.1 & 6.0 & 32530 & 45900 & $\mathrm{Na}-\mathrm{Cl}$ & 59 & 154 & 59 \\
\hline STR-114G20 & 417090.0 & 4301320.0 & Koukoumos & 82.2 & 6.5 & 33735 & 46200 & $\mathrm{Na}-\mathrm{Cl}$ & 56 & 157 & 76 \\
\hline STR-114P5 & 417561.0 & 4300935.0 & Ai pigai & 54.5 & 6.6 & 30585 & 43900 & $\mathrm{Na}-\mathrm{Cl}$ & 56 & 158 & 77 \\
\hline STR-114P9 & 417374.0 & 4301149.0 & Papaioannou & 43.9 & 6.4 & 18800 & 29600 & $\mathrm{Na}-\mathrm{Cl}$ & 56 & 153 & 73 \\
\hline STR-BP1 & 417628.1 & 4300705.3 & Vrysakia & 54.0 & 6.6 & 20870 & 31200 & $\mathrm{Na}-\mathrm{Cl}$ & 50 & 160 & 43 \\
\hline
\end{tabular}


Based on spatial distribution of the temperatures (Fig. 1B), the highest temperatures are detected along the major fault zones of the area and especially along the N.NE-S.SW to NE-SW and NW-SE directions. The temperature maxima were detected at fault intersections.

\subsection{Chemical Analysis}

The location of each sample is presented in Table 1 and in Tables 1,2 and 3 are presented the physiochemical parameters analysed in situ and in the lab. In Figure 2A, the chemical analyses were plotted in Piper diagram (Piper, 1953), in order to evaluate them hydrochemically and identify their hydrochemical type. All the samples are plotted in the same areas in the Piper and LangelierLudwing diagrams (Langelier and Ludwing, 1942, Fig. 2A, C) and all of them have $\mathrm{Na}-\mathrm{Cl}$ hydrochemical type (Table 1). In Giggenbach diagram (Giggenbach, 1980, Fig. 2B) all the samples are plotted in the same area and characterized as partially equilibrated waters.

Chloride and sodium are the dominant anion (up to $19570 \mathrm{mg} / \mathrm{L}$ ) and cation (up to $10600 \mathrm{mg} / \mathrm{L}$ ) and show high concentrations in all samples. The studied fluids showed high concentrations to a series of elements like $\mathrm{B}, \mathrm{Sr}$ and $\mathrm{Li}$, which could be associated with seawater. The concentrations of $\mathrm{Na}$, $\mathrm{Cl}, \mathrm{K}$ and TDS vary with the same way (Fig. 2D), suggesting common source (correlation coefficients $>0.95$ ). Similarly, $\mathrm{Ni}$ and $\mathrm{Cu}$ vary with the same way (correlation coefficient 0.82 ).

\subsection{Geothermometry application}

Chemical geothermometers are widely used tools in order to estimate the sub-surface reservoir temperatures in a geothermal system (Giggenbach, 1988). Geothermometers are based on the equilibrium of temperature dependent reactions between minerals and the circulating fluids (Fournier, 1973). Three geothermometers i.e. Quartz (Fournier, 1977); Na-K-Ca and Na-K-Ca with Mg correction (Fournier and Potter, 1979) were applied to the hot groundwaters of Edipsos (Table 1). The resulting temperatures are presenting large variations. The most probable reason for that could be the large percentage of sea water in the studied geothermal fluids, as the marine solutions to the geothermal fluids is one of the main causes for the disturbance for the chemical geothermometers (Dotsika, 2015).

Typically, the Quartz geothermometer is not affected by the seawater, but its results are too low (up to $60^{\circ} \mathrm{C}$; hot spring in the area present temperatures up to $82^{\circ} \mathrm{C}$ ). Possibly there is a mixing between the geothermal solution and superficial water affecting the Quartz geothermometer. The temperature which derives from the use of Na-K-Ca geothermometer is up to $164{ }^{\circ} \mathrm{C}$.

\section{Discussion - Conclusions}

In Edipsos area many hot springs occur, as a result of both active tectonics of the area and recent volcanism (Lichades volcanic center). Their temperature is up to $82^{\circ} \mathrm{C}$. The hot groundwater in Edipsos is circulating using the major fault system related with the Northern Euboea graben. As it could be seen in Fig. 1B temperature shows its maxima in NE-SW direction related with a mapped fault, which intersect, with the covered by the travertines, NW-SE fault system. 

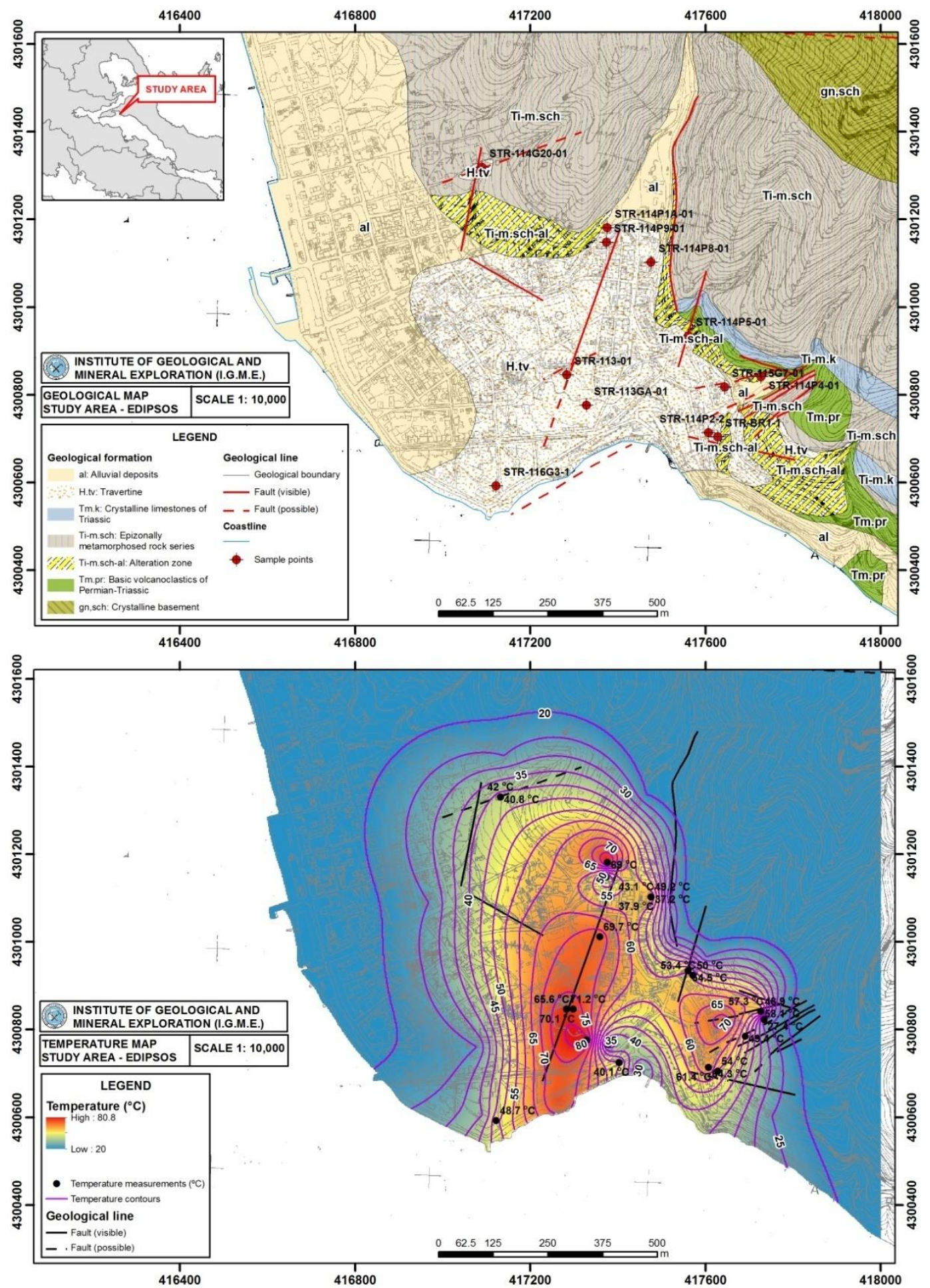

Figure 1 - (A) Geological map of the study area based on new field observations and the published geological maps (Marinos et al., 1957; Katsikatsos et al.,1984) of scale 1:50 000 as well as updated, detailed geological maps (Tzitziras, 1996; Vavassis, 2001). (B) Temperature distribution based on the hot springs and shallow wells of the area. 
Table 2 - Concentrations of major ions (in $\mathrm{mg} / \mathrm{L}$ ).

\begin{tabular}{|c|c|c|c|c|c|c|c|c|c|c|c|c|}
\hline Sample & $\mathrm{Ca}^{2+}$ & $\mathrm{Mg}^{2+}$ & $\mathrm{Na}^{+}$ & $\mathbf{K}^{+}$ & $\mathrm{HCO}_{3}{ }^{-}$ & $\mathrm{Cl}^{-}$ & $\mathrm{SO}_{4}{ }^{2-}$ & $\mathrm{NO}_{3}{ }^{-}$ & $\mathrm{NO}_{2}^{-}$ & $\mathrm{NH}_{4}{ }^{+}$ & $\mathbf{F}^{-}$ & $\mathrm{SiO}_{2}^{-}$ \\
\hline STR-116G3 & 1357 & 484 & 10133 & 354 & 489 & 18298 & 1450 & $<5.0$ & $<0.050$ & 0.3 & 4.46 & 13.8 \\
\hline STR-114P2 & 1584 & 301 & 9668 & 330 & 678 & 17589 & 1050 & $<5.0$ & $<0.050$ & 0.4 & 4.58 & 16.5 \\
\hline STR-114P4 & 1346 & 264 & 8546 & 294 & 568 & 15601 & 1000 & $<5.0$ & 0.40 & 0.5 & 4.42 & 17.6 \\
\hline STR-115G7 & 1675 & 313 & 10469 & 344 & 691 & 19006 & 1200 & $<5.0$ & $<0.050$ & 0.4 & 4.62 & 18.2 \\
\hline STR-114P8 & 1620 & 313 & 9679 & 335 & 626 & 18722 & 1200 & $<5.0$ & $<0.050$ & 0.4 & 4.52 & 17.1 \\
\hline $\begin{array}{l}\text { STR- } \\
114 \mathrm{P} 1 \mathrm{~A}\end{array}$ & 1379 & 267 & 8551 & 293 & 593 & 15601 & 1000 & $<5.0$ & $<0.050$ & 0.6 & 4.12 & 16.4 \\
\hline STR-113GA & 1650 & 322 & 10500 & 361 & 585 & 19290 & 1150 & $<5.0$ & $<0.050$ & 0.5 & 4.8 & 16.4 \\
\hline STR-113-01 & 1642 & 321 & 10219 & 351 & 620 & 18722 & 950 & $<5.0$ & $<0.050$ & 0.4 & 4.7 & 17.0 \\
\hline $\begin{array}{l}\text { STR- } \\
114 \mathrm{G} 20\end{array}$ & 1668 & 322 & 10592 & 363 & 610 & 19574 & 900 & $<5.0$ & $<0.050$ & 0.6 & 4.62 & 16.2 \\
\hline STR-114P5 & 1496 & 288 & 9459 & 321 & 657 & 17730 & 950 & $<5.0$ & $<0.050$ & 0.4 & 4.34 & 16.2 \\
\hline STR-114P9 & 864 & 174 & 5980 & 204 & 598 & 10567 & 700 & $<5.0$ & $<0.050$ & 0.4 & 3.66 & 17.7 \\
\hline STR-BP1 & 1079 & 220 & 6490 & 217 & 619 & 11843 & 700 & $<5.0$ & $<0.050$ & 0.3 & 3.42 & 16.3 \\
\hline
\end{tabular}

Table 3 - Concentrations of trace elements (in $\mu \mathrm{g} / \mathrm{L})$.

\begin{tabular}{ccccccccccccccccccccccccccc}
\hline Sample & $\mathbf{L i}$ & $\mathbf{F e}$ & $\mathbf{C r}$ & $\mathbf{M n}$ & $\mathbf{N i}$ & $\mathbf{Z n}$ & $\mathbf{R b}$ & $\mathbf{A g}$ & $\mathbf{B e}$ & $\mathbf{M o}$ & $\mathbf{C d}$ & $\mathbf{P b}$ & $\mathbf{S e}$ & $\mathbf{C o}$ & $\mathbf{V}$ & $\mathbf{S b}$ & $\mathbf{B}$ & $\mathbf{I}$ & $\mathbf{S r}$ & $\mathbf{A l}$ & $\mathbf{A s}$ & $\mathbf{C u}$ & $\mathbf{B a}$ & $\mathbf{H g}$ & $\mathbf{U}$ \\
\hline STR-116G3 & 1480 & 77 & $<50$ & 270 & 70 & $<50$ & 150 & $<5$ & $<5$ & $<10$ & $<5$ & 34 & 290 & $<10$ & 100 & $<5$ & 1030 & 580 & 11500 & $<10$ & 72 & 190 & 130 & $<0,5$ & $<5$ \\
STR-114P2 & 1900 & 2400 & $<50$ & 200 & 90 & $<50$ & 160 & $<5$ & $<5$ & $<10$ & 5.6 & 29 & 290 & $<10$ & 100 & $<5$ & 5040 & 550 & 12750 & $<10$ & 97 & 190 & 200 & $<0,5$ & $<5$ \\
STR-114P4 & 1700 & 165 & $<50$ & 180 & 80 & $<50$ & 150 & $<5$ & $<5$ & $<10$ & $<5$ & 20 & 260 & $<10$ & 100 & $<5$ & 4670 & 410 & 11250 & $<10$ & 100 & 180 & 200 & $<0,5$ & $<5$ \\
STR-115G7 & 2100 & 3170 & 55 & 160 & 97 & $<50$ & 170 & $<5$ & $<5$ & $<10$ & 5 & 22 & 290 & $<10$ & 110 & $<5$ & 5000 & 415 & 13230 & $<10$ & 97 & 200 & 220 & $<0,5$ & $<5$ \\
STR-114P8 & 2100 & 1170 & $<50$ & $<50$ & 100 & $<50$ & 170 & $<5$ & $<5$ & $<10$ & 7 & 25 & 290 & $<10$ & 120 & $<5$ & 4900 & 420 & 13170 & $<10$ & 100 & 205 & 210 & $<0,5$ & $<5$ \\
STR-114P1A & 1900 & 520 & $<50$ & $<50$ & 83 & $<50$ & 150 & $<5$ & $<5$ & $<10$ & $<5$ & 25 & 290 & $<10$ & 110 & $<5$ & 4470 & 425 & 11220 & 100 & 78 & 170 & 270 & $<0,5$ & $<5$ \\
STR-113GA & 1360 & 540 & $<50$ & $<50$ & 74 & $<50$ & 170 & $<5$ & $<5$ & $<10$ & $<5$ & $<10$ & 340 & $<10$ & 70 & $<5$ & 5400 & 430 & 11300 & $<10$ & 68 & 150 & 250 & $<0,5$ & $<5$ \\
STR-113-01 & 1370 & 2500 & 70 & 53 & 66 & $<50$ & 170 & $<5$ & $<5$ & $<10$ & $<5$ & $<10$ & 320 & $<10$ & 73 & $<5$ & 5280 & 415 & 11300 & $<10$ & 68 & 155 & 240 & $<0,5$ & $<5$ \\
STR-114G20 & 1400 & 1020 & $<50$ & $<50$ & 70 & $<50$ & 180 & $<5$ & $<5$ & $<10$ & $<5$ & $<10$ & 310 & $<10$ & $<50$ & $<5$ & 5160 & 445 & 620 & $<10$ & $<50$ & 85 & 130 & $<0,5$ & $<5$ \\
STR-114P5 & 1320 & 2900 & $<50$ & 140 & 69 & $<50$ & 170 & $<5$ & $<5$ & $<10$ & $<5$ & $<10$ & 300 & $<10$ & 68 & $<5$ & 4750 & 535 & 10700 & $<10$ & 64 & 140 & 150 & $<0,5$ & $<5$ \\
STR-114P9 & 860 & 880 & $<50$ & 210 & $<50$ & $<50$ & 107 & $<5$ & $<5$ & $<10$ & $<5$ & $<10$ & 200 & $<10$ & $<50$ & $<5$ & 3700 & 300 & 640 & $<10$ & 60 & 100 & 130 & $<0,5$ & $<5$ \\
STR-BP1 & 940 & 870 & $<50$ & 160 & 53 & $<50$ & 130 & $<5$ & $<5$ & $<10$ & $<5$ & $<10$ & 210 & $<10$ & $<50$ & $<5$ & 3650 & 325 & 790 & $<10$ & $<50$ & 100 & 140 & $<0,5$ & $<5$ \\
\hline
\end{tabular}



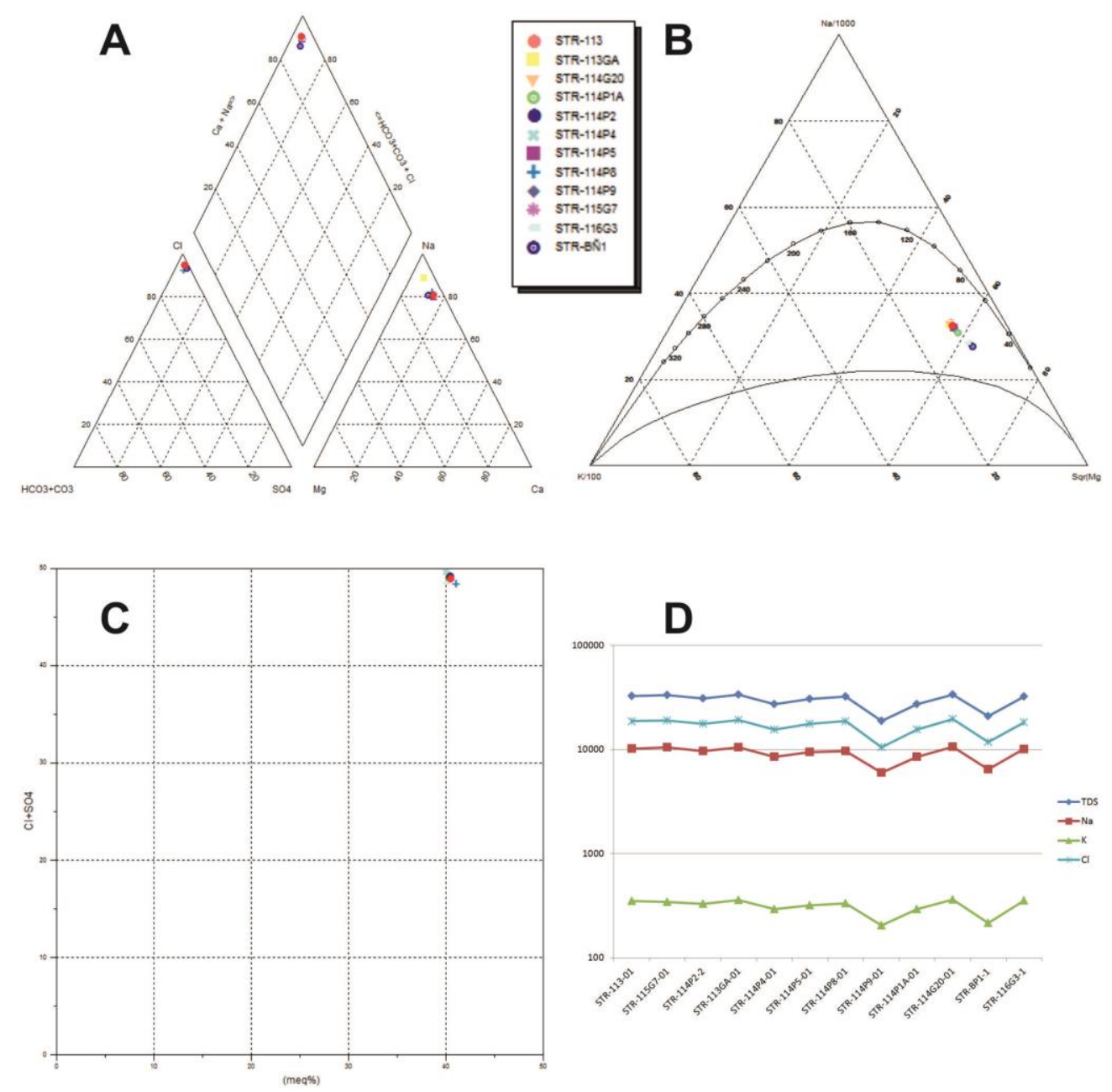

Figure 2 - Chemical composition of groundwater samples plotted in (A) Piper trilinear diagram. (B) Giggenbach trilinear diagram. (C) Ludwing-Langelier diagram. (D) Logarithmic diagram presenting the co-varying of TDS, $\mathrm{Na}, \mathrm{K}$ and $\mathrm{Cl}$.

The vast deposition of thermogenic travertines and the high Ca concentrations suggests that the hot groundwater at some point meet and dissolve carbonates rocks. So, the hot water enriches in $\mathrm{Ca}$ and deposits thermogenic travertine at the surface due to pressure and temperature change.

Similarly, the co-variation and the concentrations of $\mathrm{Ni}$ and $\mathrm{Cu}$ suggesting influence of the ultramafic rocks from the ophiolitic sequence. Kanellopoulos and Argyraki (2013) and Kanellopoulos and Mitropoulos (2013) have shown that element like $\mathrm{Ni}, \mathrm{Cr}, \mathrm{Cu}$ etc. are present in noticeable concentrations in the soil and the cold groundwater of the greater area of NW Euboea and are related with the ultramafic rocks from the ophiolitic sequence.

The high concentrations in $\mathrm{Cl}$ (up to $19570 \mathrm{mg} / \mathrm{L}$ ), $\mathrm{Na}$ (up to $10600 \mathrm{mg} / \mathrm{L}$ ) and in other elements that could be associated with seawater, combined with isotopic results (Mitropoulos and Kita, 1997; D’Alessandro et al., 2014; Dotsika, 2015) strongly suggests high seawater participation at the system. 

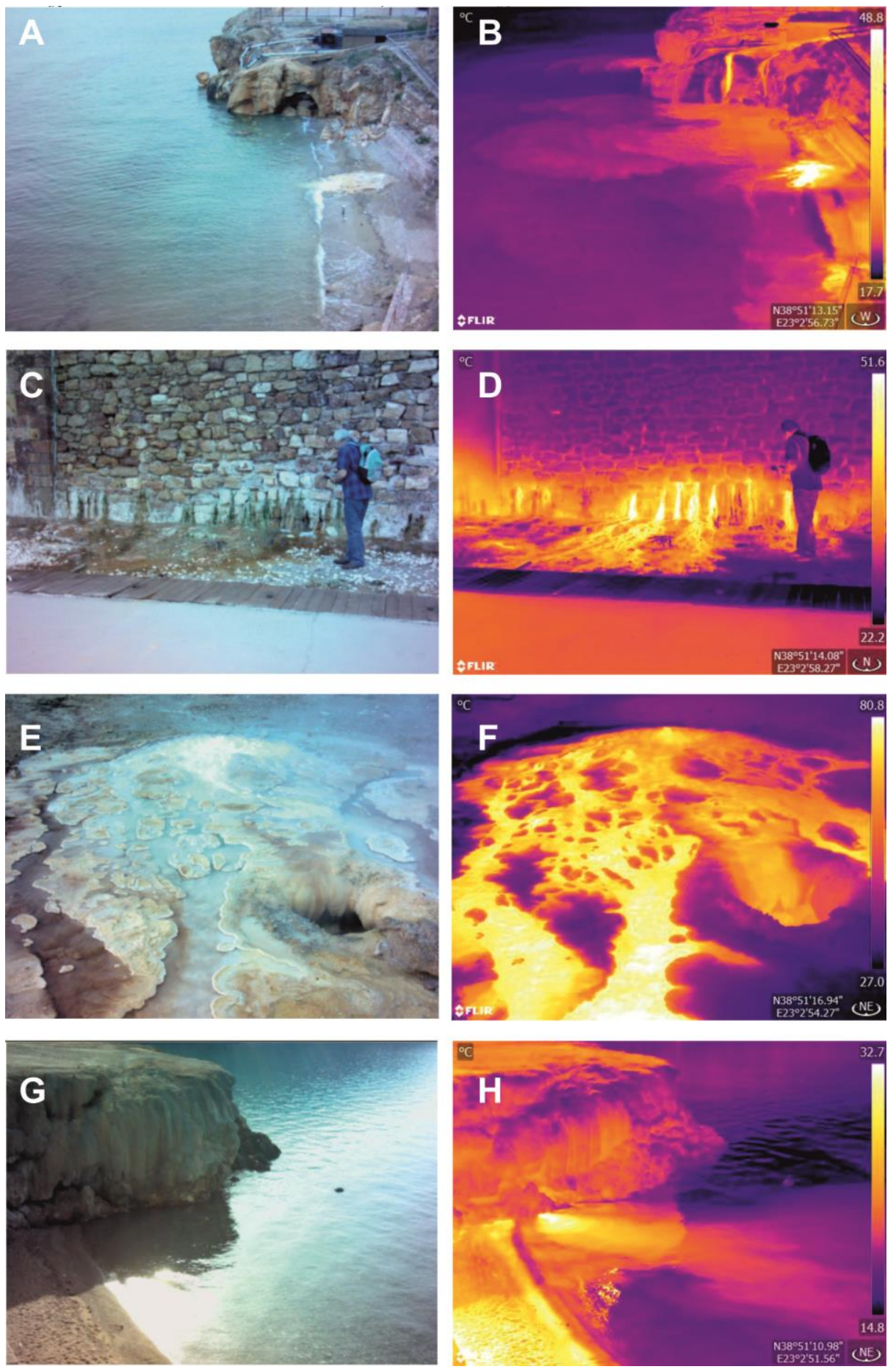

Figure 3 - Paired views of Edipsos hot springs pictures and corresponding thermal image of the same area. In the right side of each thermal picture, a colour column shows the temperature scale corresponding to the colors. (A and B) Near the sea hot spring discharge and the spring plume into the sea. (C and D) Wall with several small hot spring discharges. (E and $\mathbf{F}$ ) Terrestrial hot spring discharge. ( $G$ and $H$ ) Submarine hot spring discharging in the base of a thermogenic travertine cape and the spring plume into the sea. 
At the same time water and gas isotopic studies (Shimizu et al., 2005; D`Alessandro et al., 2014; Dotsika, 2015) suggests that the hot springs of Edipsos are fed by deep parent geothermal fluid mixed with seawater. Possibly related with the volcanic center of Lichades and the magma chamber, which it has recently detected at $8 \mathrm{~km}$ depth (Karastathis et al., 2011).

Geochemical study in the cold groundwaters of the area, show that the main cold aquifers are not affected by the hot groundwaters (Kanellopoulos, 2006, 2011; Kanellopoulos and Mitropoulos, 2013). Suggesting that the hot reservoirs or/and the pathway of the hot groundwater, are not in hydraulic connection with the main shallower cold aquifers.

The application of chemical geothermometers in Edipsos hot groundwater is problematic. The samples are characterized as partially equilibrated waters (Fig. 2B) and the resulting temperatures are presenting large variations. The high percentage of seawater participation is most probably one of the main reasons (Dotsika, 2015). Taking under consideration that the hydrochemical type of the samples is $\mathrm{Na}-\mathrm{Cl}$ and the fact that $\mathrm{Na}, \mathrm{K}$ and $\mathrm{Ca}$ alongside with $\mathrm{Cl}$ are the main ions, support the idea that $\mathrm{Na}-\mathrm{K}-\mathrm{Ca}$ geothermometer could be considered the most representative geothermometer for the studied geothermal fluids. According to Na-K-Ca geothermometer estimations, the expected temperature of a potential geothermal reservoir is up to $\sim 160{ }^{\circ} \mathrm{C}$.

Therefore, the geochemical study of Edipsos hot groundwater shows that the water chemistry is controlled by the following three factors: i) a deeper magmatic source, ii) the chemical composition of the local rocks (ultramafic and carbonates) and iii) the high participation of the sea water.

Even though several studies have been conducted in the area, the detailed underground circulation of the hot groundwater still remains vague. Does the hot groundwater rise from greater depths using the dominant faults of the area, or is there a reservoir in the broader area, possibly in carbonate rocks? In that case which is the temperature of the geothermal fluid in the reservoir? A systematic geothermal deep drilling project could give the answers.

\section{Acknowledgements}

This study was funded by the National Strategic Reference Framework (NSRF, 350913). The authors would like to thank the local authorities, the local population and especially the Director of the Public Properties Company-Edipsos branch, Ilia Siakantari for the co-operation during the field work.

\section{References}

D`Alessandro, W., Brusca, L., Kyriakopoulos, K., Bellomo, S. and Calabrese, S., 2014. A geochemical traverse along the "Sperchios Basin e Evoikos Gulf" graben (Central Greece): Origin and evolution of the emitted fluids, Marine and Petroleum Geology, 55, 295-308.

Dotsika, E., 2015. H-O-C-S isotope and geochemical assessment of the geothermal area of Central Greece, Journal of Geochemical Exploration, doi: 10.1016/j.gexplo.2014.11.008

Fournier, R.O., 1973. Silica in thermal waters: laboratory and field investigations, Proc. International Symposium on Hydrogeochemistry and Biogeochemistry, Tokyo, 122-139.

Fournier, R.O. 1977. A review of chemical and isotopic geothermometers for the geothermal systems. In: Proc. Symp. on geothermal energy, Cento Scient. Prog., Ankara, Turkey, 133-143.

Fournier, R.O. and Potter, R.W., 1979. Magnesium correction to the Na-K-Ca chemical geothermometer, Geochim. Cosmochim, Acta, 43, 1543-1550.

Georgalas, G.C., 1938. Le volcans des 1^les Likhades et de Hagios Ioannis (Kammena Vourla), Praktika Academia Athinion, 13, 86-98.

Giggenbach, W.F., 1988. Geothermal solute equilibria: derivation of Na-K-Mg-Ca geoindicators. Geochim, Cosmochim, Acta, 52, 2749-2765.

Gkioni, G., 1983. Inventory of hot and mineral springs of Greece, I, Aegean Sea, Hydrological and Hydrogeological Investigation Report No. 39, IGME, Athens (in Greek). 
Glassley, W., 2015. Geothermal Energy: Renewable energy and the environment (Second edition), CRC Press, Taylor \& Francis Group.

Marinos, G., Anastopoulou, I., Maratou, G., Melidoni, N. and Andronopoulou, V., 1957. Geological map of Pelasgia in 1: 50,000, I.G.M.E.

Katsikatsos, G., Mettos, A. and Vidakis, M., 1984. Geological map of Istiea in 1: 50,000, I.G.M.E.

Kanellopoulos, C., 2006. Geochemical research on the distribution of metallic and other elements to the groundwater in Fthiotida Prefecture and N. Euboea, Master Thesis, University of Athens, Greece (in Greek).

Kanellopoulos, C., 2011. Geochemical research on the distribution of metallic and other elements to the cold and thermal groundwater, soils and plants in Fthiotida Prefecture and N. Euboea, Environmental impact, Unpub. Ph.D. Thesis, University of Athens, Greece (in Greek).

Kanellopoulos, C. and Argyraki, A., 2013. Geochemical impact of hot springs and ultramafic rocks on soil, groundwater and vegetation: The case of NW Euboea, Greece, Chemie der Erde Geochemistry, 73, 519-532.

Kanellopoulos, C. and Mitropoulos, P., 2013. Geochemical effect of the rock chemistry and the anthropogenic activities on groundwater: the case of NW Euboea, Greece, Bull. Geol. Soc. Greece, XLVII/2, 942-952.

Kanellopoulos, C., 2013a. Distribution, depositional faces and mineralogical study of active travertine systems in Northern Euboea and Eastern Central Greece, Central European Journal of Geosciences, 4(4), 545-560.

Kanellopoulos, C., 2013b. Various morphological types of thermogenic travertines in northern Euboea and Eastern Central Greece, Bull. Geol. Soc. Greece, XLVII/3, 1929-1938.

Karastathis, V.K., Papoulia, J., Di Fiore, B., Makris, J., Tsambas, A., Stampolidis, A. and Papadopoulos, G.A., 2011. Deep structure investigations of the geothermal field of the North Euboean Gulf, Greece, using 3-D local earthquake tomography and Curie Point Depth analysis, Journal of Volcanology and Geothermal Research, 206, 106-120.

Langeller, W. and Ludwig, H., 1942. Graphical methods for indicating the mineral character of natural waters, $J W W A, 34,335-352$.

Mercier, J.L., Sorel, D., Vergely, P. and Simeakis, K., 1989. Extensional tectonic regimes in the Aegean basins during the Cenozoic, Basin Research, 2, 49-71.

Mitropoulos, P. and Kita, I., 1997. Geochemistry of oxygen and hydrogen isotopes in Greek regional waters, Proc 4th Hydrogeol Congr, Hydrogeol. Commission of Greece, Athens, 285-291.

Mountrakis, D., 1986. The Pelagonian zone in Greece: A polyphase deformed fragment of the Cimmerian continent and its role in the geotectonic evolution of the Eastern Mediterranean, Journal of Geology, 94, 335-347.

Orfanos, G. and Sfetos, K.S., 1975. Hydrogeological study of Kamena Vourla area, IGME (in Greek).

Palyvos, N., Bantekas, I. and Kranis, H., 2006. Transverse fault zones of subtle geomorphic signature in northern Evia island (central Greece extensional province): An introduction to the Quaternary Nileas graben, Geomorphology, 76, 363-374.

Pe-Piper, G. and Piper, D., 2002. The igneous rocks of Greece, the anatomy of an orogeny, Gebruder Borntraeger, Berlin.

Piper, A.M., 1953. A Graphic Procedure in the Geochemical Interpretation of Water Analysis, United States Geological Survey, Washington D.C.

Sfetsos, K.S., 1988. Inventory of hot and mineral springs of Greece, III, Mainland Greece, Hydrological and Hydrogeological Investigation Report No. 39, IGME, Athens (in Greek).

Shimizu, A., Sumino, H., Nagao, K., Notsu, K. and Mitropoulos, P., 2005. Variation in noble gas isotopic composition of gas samples from the Aegean arc, Greece, Journal of Volcanology and Geothermal Research, 140(4), 321-339.

Tzitziras, A., 1996. Geotechnical study for the detour road of Edipsos, IGME, Athens (in Greek).

Vavassis, I., 2001. Geology of the Pelagonian zone in Northern Evia Island (Greece): Implications for the geodynamic evolution of the Hellenides, These de doctorat, Univ. de Lausanne.

Xatzis, M., Kavouridis, Th., Bakalopoulos, P. and Xenakis, M., 2008. Investigation and determination of Northern Euboea geothermal fields. IGME, Athens (in Greek). 